\title{
The role of leaders' emotions
}

\author{
Kornélia Lazányi \\ Corvinus University of Budapest \\ 1093 Budapest, Fövám 8, Hungary
}

\begin{abstract}
Western cultures support the notion that the ideal 'professional' behaviour for a leader is primarily rational and carefully controlled emotionally. The relationship of reason and emotion is often played out as one of mutual exclusion, and moreover as one representing hierarchy of leaders and followers. Power positions in most organizations are ritually emphasized through strict emotional control/suppression. Thus this display of unemotional rationality is held to be synonymous with control, may actually belie emotional and psychical insanities, and indicate organizational incongruities. Since, emotions play crucial role in the regulation of workplace relations. Negative emotions are the basis of awareness and positive ones are that of trust, and hence they both are needed in everyday situations. Leaders' emotions can be used as tools to motivate and to express individualist attention and caring. However, this use of emotions as tools may come at a price for those leaders who are less apt at emotion regulation. In sum, workplace is an emotional place and it is of best interest of the organizational members, - both the leaders and those led, - to understand the leaders' genuine and displayed emotions, their antecedents and their consequences.
\end{abstract}

Key words: emotion, emotional labour, leadership

\section{Introduction}

The investigation of emotions at workplaces is a relatively new research area of organisational behaviour. In Western societies, emotions have so far been regarded as irrational and dysfunctional factors, and incorporated in models as disturbing factors at the very best (Arvery et al, 1998; Ashforth and Humphrey, 1995; Muchinsky, 2000). Concurrently with a growing literature on workplace climate, work morale, and emotional intelligence (EI), researchers have started to focus more and more on the investigation of the emotional component of working. Despite this tendency, genuine emotions of leaders (more often than not different from those displayed) are explored to a very little extent.

An interest taken in the role of emotions in the leadership process is mostly the invention of the twenty-first century. In literature on leadership, the desirability of 'emotional arousal states' leaders should create in others is highlighted. In most approaches, numerous behaviours with emotional implications, such as lending support, developing trusting relations, exhibiting moral integrity, providing safety, fostering collaboration, offering intellectual stimulation, encouraging organizational learning, and practicing consultative and shared decision making, are endorsed (Leithwood et al, 1999). Such leadership skills have been variously referred to as "socioemotional" orientation (Bales, 1950), "leader consideration" (Fleishman, 1957), or "human relations skills" (Likert, 1967). Goleman et al. (2003) even argue that emotions and emotional intelligence lie at the core of effective leadership. In line with this view, George (2000) and Dasborough and Ashkanasy (2002) claim that leadership is an emotional process in which leaders express emotions and try to arouse emotions in their subordinates. Control of the emotions of their staff is thus one of the most important means by which leaders can improve staff performance and productivity (Humphrey, 2002).

The power of a leader's emotions as a leadership tool is appreciated by all leadership styles that flatter the "charismatic" aspect of a leader. Thus, charismatic leaders, resonant leaders, and transformational leaders all use emotions to motivate employees, communicate a vision, and excite followers to work towards long-term ideals and strategic objectives. These competencies are to establish warm, empathic, non-directive, trusting relations with subordinates, so empathy, active listening and other interpersonal skills are supposed to be inevitable for leaders. The focus is mostly on the emotions the leader stimulates in others in the process of generating productive behaviour. But throughout all the theories the emotions of a leader were hardly ever considered.

What is more, leaders are supposed to be unemotional. Power positions in most organizations are ritually emphasized through strict emotional control/suppression. A rational attitude is a must for leaders. Accordingly, emotions in organizations are political. In literature, such skills as problem solving, strategic planning, and even reflective practice are considered from an exclusively rational perspective. The display of unemotional rationality is held to be synonymous with control. However, this concept is essentially mistaken because even the most rational leader is subject to his/her own transrational values that are sustained by his/her own emotions (Hodgkinson, 1990). Reason itself is not free from an emotional foundation and, even in the purest of intellectual moments; emotions are present because of the mind itself being a seamless blend of thinking and feeling (Damasio, 1994).

Organizations have a variety of mechanisms at their disposal to regulate emotions at the workplace. These mechanisms mostly aim to either prevent emotions from arising in the first 
place or "safely" control those as may arise, regardless of the fact that emotions can have positive effects. Emotional display rules exist in each and every workplace. These include expectations that organizational members be pleasant and helpful, and express a minimum of hostility and negative emotions (Cropanzano et al., 2000). Mann (1999), for example, found similar rates of performance of emotional management occurring among colleagues to those occurring between staff and customers. Respondents reported that in 53\% of interactions, they had smiled because this was expected of them, rather than because a smile expressed their true feelings. These findings suggest that emotional management within organizational boundaries should be paid more attention by researchers. Strazdins (2002) supports this point of view, claiming that emotional labour is not restricted to particular professional roles, but managers as well as workmates perform emotional management. Briner and Totterdell (2002) claim that managerial jobs include an additional element of emotional labour, because tasks will probably be performed better if leaders fake enthusiasm in order to motivate their staff. Mann (1999) also found that emotional labour is influenced by roles and status. Emotional management by leaders has contents and meanings different from those associated with emotional management by subordinates.

\section{Material and methods}

I have researched 36 physicians at the University of Debrecen Medical and Health Sciences Center. The participation in the research was voluntary. 9 leaders (heads of institutes, departments, wards) and 27 non-leaders (from now on subordinates) filled out the questionnaire. I have used the Positive and Negative Affect Schedule - Expanded Form (PANAS-X) questionnaire (Watson and Clark, 1994) to investigate the true and displayed emotions of the leaders and their subordinates.

The PANAS-X contains 60 emotions that can be compressed into two general (Positive Affect, Negative Affect), or 11 basic (Fear, Hostility, Guilt, Sadness, Joviality, SelfAssurance, Attentiveness, Shyness, Fatigue, Serenity, Surprise) emotion scales.

My questionnaire contained the PANAS-X twice. First the respondents were asked to rate the listed emotions on the basis how they feel each one of them in the course of their daily work. Secondly they had to rate them on the basis of their emotional displays. They had to score on a five point scale how often and how intensely they were displaying a given emotion.

\section{Results and discussion}

Emotions are feelings experienced, interpreted, controlled, and expressed (Thoits, 1989; Mills and Kleinman, 1988). They arise from social interactions, and are influenced by social, cultural, interpersonal, and situational factors (Martin, 1999). Emotions are aroused by the individual interpretation of events.
According to Fisher and Ashkanasy (2000), emotions can be defined as the complex of cognitive and physiological processes, willingness to act, and subjective feelings. Emotions are displayed through many channels, including kinesics (such as bodily posture and hand gestures), prosodic (such as vocal intonation and pitch) and facial expressions.

Emotions are individual, although socially constructed to a degree (Hare, 1986). According to Fineman (1993), there exists a social consciousness of what are the correct emotions in specific situations. Individuals create meaning and content about one's own and others' emotions on the basis of emotional codes and 'schema' that contain guidelines for socially acceptable emotions within a given culture. According to Lazarus (1991), the variety, quality and intensity of emotions reflect how the person in question interprets and reacts to ongoing organizational events.

Human emotions can be divided into two broad categories. These two categories are called negative and positive, and should be regarded as polarities. (These descriptions do not imply any value judgment, but are designed to signify senses of action induced.) Negative emotions are fuelled by an underlying fear of the unknown or other people's actions, and a need to control or stop them to avoid being harmed (Watson and Clark, 1984). On the other hand, positive emotions are fuelled by an underlying desire for unity and enjoyment

Positive emotions enhance creativity, encourage helping behaviour and cooperation, and reduce aggression against either the organization or people. A negative affect leads to a more thorough treatment of information and hence better judgments in situations where difficult and complex problems need to be solved. Sad people seek and consider more information and process persuasive messages more thoroughly. In contrast, individuals in a positive mood tend to prefer the use of simple heuristics and decisional shortcuts, or base their judgments on stereotypes.

While emotions alter rapidly, they are intense and represent responses to a particular event. They play a number of functional roles, such as preparing for actions, steering attention, sharpening memory, adapting behaviour to tasks and goals, ensuring adaptation to changing social requirements, affecting the behaviour of other people and supporting decision-making processes (Reilly and Seibert, 2003). Very often it is emotions felt that give leaders a hand in replying to problems too complex to analyse.

Table 1 shows the scores given to 60 different emotions by leaders and by subordinates. I have indicated the emotions that had the greatest differences between that of a leader and that of a subordinate. Letter ' $A$ ' spotlights emotions, which are felt more often or more intense by leaders. Letter ' $B$ ' highlights emotions that are felt by leaders less often or less intense than by subordinates.

The genuine emotions of leaders and subordinates are different in the field of most basic emotive factors as well. This difference may be the consequence of the different work demands and expectations, but also could serve as a basis for the internal selection process for an organization (Figure 1). 
Table 1: Differences in genuine emotions of leaders and subordinates

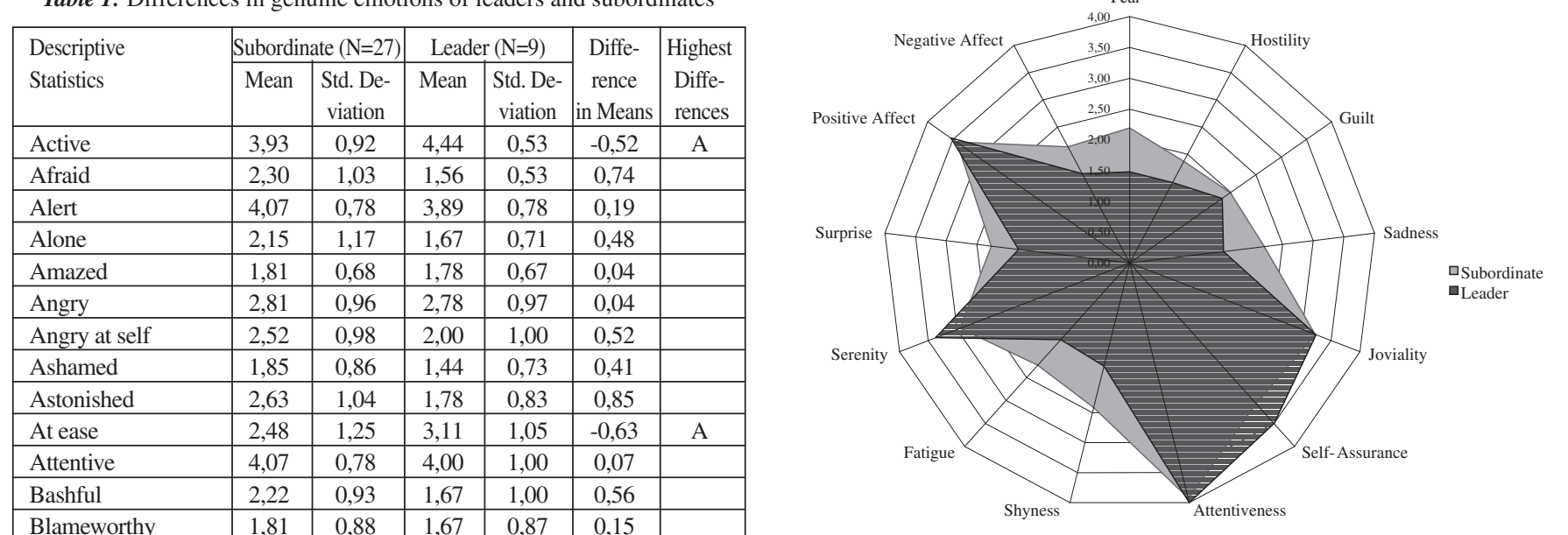

\begin{tabular}{|l|l|l|l|l|l|l|}
\hline Blameworthy & 1,81 & 0,88 & 1,67 & 0,87 & 0,15 & \\
\hline Blue & 1,81 & 0,96 & 1,11 & 0,33 & 0,70 & \\
\hline Bold
\end{tabular}

\begin{tabular}{|l|c|c|c|c|c|c|} 
Bold & 1,81 & 0,96 & 1,11 & 0,33 & 0,70 & \\
\hline Calm & 3,48 & 0,98 & 4,11 & 0,93 & $-0,63$ & A
\end{tabular}

\begin{tabular}{|l|l|l|l|l|l|l} 
Calm & 3,44 & 1,37 & 4,11 & 0,60 & $-0,67$ & A \\
\hline
\end{tabular}

\begin{tabular}{|l|l|l|l|l|l|l|}
\hline Cheerful & 3,70 & 0,72 & 4,00 & 0,50 & $-0,30$ & \\
\hline Concentrating & 3,85 & 0,86 & 4,00 & 0,71 & $-0,15$ &
\end{tabular}

\begin{tabular}{|l|l|l|l|l|l|l|}
\hline Concentrating & 3,85 & 0,86 & 4,00 & 0,71 & $-0,15$ & \\
\hline Confident & 3,74 & 0,71 & 4,00 & 0,50 & $-0,26$ & \\
\hline Daring & 2,63 & 0,97 & 3,00 & 1,32 & $-0,37$ & \\
\hline
\end{tabular}

\begin{tabular}{|l|c|c|c|c|c|c|}
\hline Daring & 2,63 & 0,97 & 3,00 & 1,32 & $-0,37$ & \\
\hline Delighted & 2,48 & 0,98 & 2,22 & 1,09 & 0,26 & \\
\hline Determined & 3,74 & 0,71 & 4,11 & 1,05 & $-0,37$ & \\
\hline Ding
\end{tabular}

\begin{tabular}{|l|l|l|l|l|l|l|}
\hline Disgusted & 1,67 & 0,88 & 1,00 & 0,00 & 0,67 & \\
\hline Disgusted with self & 1,30 & 0,72 & 1,11 & 0,33 & 0,19 & \\
\hline Dissisfed
\end{tabular}

\begin{tabular}{|l|l|l|l|l|l|l|}
\hline Disgusted with self & 1,30 & 0,72 & 1,11 & 0,33 & 0,19 & \\
\hline Dissatisfied with self & 3,11 & 1,09 & 3,00 & 1,12 & 0,11 & \\
\hline Distressed & 2,07 & 1,14 & 1,67 & 0,71 & 0,41 & \\
\hline Downhearted & 2,33 & 0,83 & 1,56 & 0,73 & 0,78 & \\
\hline Drowsy & 1,89 & 0,85 & 1,22 & 0,67 & 0,67 &
\end{tabular}

\begin{tabular}{|l|c|c|c|c|c|c|}
\hline Drowsy & 2,33 & 0,83 & 1,56 & 0,73 & 0,78 & \\
\hline Energetic & 1,89 & 0,85 & 1,22 & 0,67 & 0,67 & \\
\hline Enthusiastic & 3,74 & 0,81 & 4,00 & 0,87 & $-0,26$ & \\
\hline
\end{tabular}

\begin{tabular}{|l|c|c|c|c|c|c|}
\hline Enthusiastic & 2,48 & 1,12 & 2,33 & 0,71 & 0,15 & \\
\hline Excited & 2,89 & 1,09 & 2,33 & 1,22 & 0,56 & \\
\hline Fearless & 1,93 & 1,07 & 2,67 & 1,22 & $-0,74$ & A \\
\hline
\end{tabular}

\begin{tabular}{|l|c|c|c|c|c|c|}
\hline Fightened & 1,93 & 1,07 & 2,67 & 1,22 & $-0,74$ & A \\
\hline Guilty & 1,96 & 1,16 & 1,22 & 0,44 & 0,74 & \\
\hline & 1,89 & 0,85 & 1,78 & 1,09 & 0,11 & \\
\hline
\end{tabular}

\begin{tabular}{|l|c|c|c|c|c|c|}
\hline Guilty & 1,89 & 0,85 & 1,78 & 1,09 & 0,11 & \\
\hline Happy & 3,41 & 1,01 & 3,78 & 0,97 & $-0,37$ & \\
\hline Hostile & 1,89 & 1,01 & 1,33 & 0,71 & 0,56 & \\
\hline
\end{tabular}

\begin{tabular}{|l|c|c|c|c|c|c|}
\hline Hostile & 1,89 & 1,01 & 1,33 & 0,71 & 0,56 & \\
\hline Inspired & 2,44 & 0,89 & 2,89 & 1,27 & $-0,44$ & \\
\hline Interested & 4,11 & 0,58 & 4,22 & 0,97 & $-0,11$ & \\
\hline Irritable & 2,56 & 1,12 & 2,22 & 0,97 & 0,33 & \\
\hline
\end{tabular}

\begin{tabular}{|l|c|c|c|c|c|c|}
\hline Irritable & 4,1 & 0,58 & 4,22 & 0,97 & $-0,11$ & \\
\hline Jittery & 2,56 & 1,12 & 2,22 & 0,97 & 0,33 & \\
\hline Joyfu & 1,89 & 0,85 & 1,44 & 0,73 & 0,44 & \\
\hline
\end{tabular}

\begin{tabular}{|l|lll|l|l|l|}
\hline Joyful & 3,15 & 0,99 & 3,33 & 0,71 & $-0,19$ & \\
\hline Lively & 3,78 & 0,64 & 3,89 & 1,05 & $-0,11$ & \\
\hline Loathing & 1,74 & 1,02 & 1,11 & 0,33 & 0,63 & \\
\hline
\end{tabular}

\begin{tabular}{|l|l|l|l|l|l|l|}
\hline Loathing & 1,74 & 1,02 & 1,11 & 0,33 & 0,63 & \\
\hline Lonely & 1,96 & 1,32 & 1,67 & 1,12 & 0,30 & \\
\hline Nervoly
\end{tabular}

\begin{tabular}{|l|c|c|c|c|c|c|}
\hline Lonely & 1,96 & 1,32 & 1,67 & 1,12 & 0,30 & \\
\hline Nervous & 2,89 & 1,22 & 1,78 & 0,83 & 1,11 & $\mathrm{~B}$ \\
\hline Proud & 3,11 & 1,05 & 3,11 & 0,60 & 0,00 & \\
\hline Relaxed & 2,74 & 1,06 & 2,89 & 1,36 & $-0,15$ & \\
\hline Sad & 2,78 & 1,09 & 1,67 & 0,50 & 1,11 & $\mathrm{~B}$ \\
\hline Scared & 1,89 & 0,97 & 1,44 & 0,73 & 0,44 & \\
\hline Scornful & 1,67 & 0,92 & 1,56 & 1,13 & 0,11 & \\
\hline Shaky & 2,59 & 0,89 & 1,44 & 0,53 & 1,15 & $\mathrm{~B}$ \\
\hline Sheepish & 2,67 & 1,11 & 1,67 & 0,50 & 1,00 & $\mathrm{~B}$ \\
\hline Shy & 3,04 & 0,98 & 2,00 & 1,00 & 1,04 & $\mathrm{~B}$ \\
\hline Sleepy & 1,89 & 0,80 & 1,22 & 0,44 & 0,67 & \\
\hline Sluggish & 2,07 & 0,83 & 1,67 & 0,71 & 0,41 & \\
\hline Strong & 3,63 & 0,63 & 4,11 & 1,05 & $-0,48$ & \\
\hline Surprised & 2,37 & 0,93 & 1,89 & 0,78 & 0,48 & \\
\hline Timid & 2,15 & 1,20 & 1,56 & 0,53 & 0,59 & \\
\hline Tired & 3,15 & 1,17 & 2,56 & 1,33 & 0,59 & \\
\hline Upset & 2,70 & 1,10 & 1,78 & 0,83 & 0,93 & \\
\hline
\end{tabular}


Table 2: Difference between genuine and displayed emotions of leaders and of subordinates

\begin{tabular}{|c|c|c|c|c|}
\hline $\begin{array}{l}\text { Difference between } \\
\text { true and displayed } \\
\text { emotions }\end{array}$ & $\begin{array}{l}\text { Subordinate } \\
\quad(\mathrm{N}=27)\end{array}$ & $\begin{array}{l}\text { Emotional } \\
\text { Labour }\end{array}$ & $\begin{array}{l}\text { Leader } \\
(\mathrm{N}=9)\end{array}$ & $\begin{array}{l}\text { Emotional } \\
\text { Labour }\end{array}$ \\
\hline Active & 0,11 & & 0,11 & \\
\hline Afraid & 0,22 & & 0,26 & \\
\hline Alert & $-0,22$ & & 0,44 & \\
\hline Alone & 0,11 & & 0,37 & \\
\hline Amazed & 0,44 & B & $-0,11$ & \\
\hline Angry & 0,11 & & 0,37 & \\
\hline Angry at self & 0,33 & & 0,37 & \\
\hline Ashamed & 0,00 & & 0,07 & \\
\hline Astonished & 0,00 & & 0,44 & \\
\hline At ease & 0,11 & & 0,04 & \\
\hline Attentive & $-0,22$ & & 0,22 & \\
\hline Bashful & 0,56 & B & 0,30 & \\
\hline Blameworthy & 0,11 & & $-0,15$ & \\
\hline Blue & $-0,11$ & & 0,33 & \\
\hline Bold & 0,00 & & 0,19 & \\
\hline Calm & $-0,22$ & & $-0,11$ & \\
\hline Cheerful & 0,11 & & 0,30 & \\
\hline Concentrating & $-0,33$ & $\mathrm{~A}$ & $-0,30$ & $\mathrm{~A}$ \\
\hline Confident & $-0,33$ & & 0,30 & \\
\hline Daring & $-0,22$ & & $-0,11$ & \\
\hline Delighted & $-0,44$ & $\mathrm{~A}$ & 0,15 & \\
\hline Determined & 0,00 & & 0,07 & \\
\hline Disgusted & $-0,44$ & $\mathrm{~A}$ & 0,19 & \\
\hline Disgusted with self & $-0,11$ & & $-0,11$ & \\
\hline Dissatisfied with self & 0,56 & B & 0,63 & B \\
\hline Distressed & 0,22 & & $-0,07$ & \\
\hline Downhearted & $-0,11$ & & $-0,04$ & \\
\hline Drowsy & 0,00 & & 0,30 & \\
\hline Energetic & $-0,22$ & & 0,22 & \\
\hline Enthusiastic & 0,00 & & 0,07 & \\
\hline Excited & 0,33 & & 0,37 & \\
\hline Fearless & $-0,22$ & & $-0,56$ & $\mathrm{~A}$ \\
\hline Fightened & 0,00 & & 0,19 & \\
\hline Guilty & 0,56 & B & $-0,37$ & $\mathrm{~A}$ \\
\hline Happy & $-0,11$ & & 0,33 & \\
\hline Hostile & $-0,11$ & & 0,30 & \\
\hline Inspired & $-0,44$ & A & $-0,11$ & \\
\hline Interested & 0,00 & & 0,19 & \\
\hline Irritable & $-0,11$ & & 0,41 & \\
\hline Jittery & 0,33 & & 0,19 & \\
\hline Joyful & 0,33 & & 0,04 & \\
\hline Lively & $-0,33$ & A & 0,26 & \\
\hline Loathing & 0,00 & & $-0,04$ & \\
\hline Lonely & 0,44 & $\mathrm{~B}$ & $-0,07$ & \\
\hline Nervous & 0,11 & & 0,59 & B \\
\hline Proud & 0,33 & & 0,07 & \\
\hline Relaxed & 0,22 & & $-0,30$ & $\mathrm{~A}$ \\
\hline Sad & $-0,67$ & B & 0,44 & B \\
\hline Scared & 0,22 & & $-0,04$ & \\
\hline Scornful & 0,22 & & 0,30 & \\
\hline Shaky & 0,00 & & 0,30 & \\
\hline Sheepish & $-0,11$ & & 0,59 & B \\
\hline Shy & $-0,22$ & & 0,44 & \\
\hline Sleepy & 0,22 & & 0,33 & \\
\hline Sluggish & $-0,33$ & & 0,22 & \\
\hline Strong & $-0,22$ & & 0,00 & \\
\hline Surprised & $-0,11$ & & $-0,15$ & $\mathrm{~A}$ \\
\hline Timid & 0,33 & & 0,04 & \\
\hline Tired & 0,22 & & 0,26 & \\
\hline Upset & $-0,22$ & & 0,52 & B \\
\hline
\end{tabular}

Table 3: Difference between emotions displayed by leaders and subordinates

\begin{tabular}{|c|c|c|c|c|c|c|}
\hline \multirow{2}{*}{$\begin{array}{l}\text { Descriptive } \\
\text { Statistics }\end{array}$} & \multicolumn{2}{|c|}{ Subordinate $(\mathrm{N}=27)$} & \multicolumn{2}{|c|}{ Leader $(\mathrm{N}=9)$} & \multirow{2}{*}{$\begin{array}{c}\text { Diffe- } \\
\text { rence } \\
\text { in Means }\end{array}$} & \multirow{2}{*}{$\begin{array}{c}\text { Highest } \\
\text { Diffe- } \\
\text { rences } \\
\end{array}$} \\
\hline & Mean & \begin{tabular}{|c|} 
Std. De- \\
viation \\
\end{tabular} & Mean & $\begin{array}{c}\text { Std. De- } \\
\text { viation }\end{array}$ & & \\
\hline Active & 3,81 & 0,96 & 4,33 & 0,71 & $-0,52$ & \\
\hline Afraid & 2,04 & 1,34 & 1,33 & 0,71 & 0,70 & \\
\hline Alert & 3,63 & 1,24 & 4,11 & 0,60 & $-0,48$ & \\
\hline Alone & 1,78 & 0,97 & 1,56 & 1,13 & 0,22 & \\
\hline Amazed & 1,93 & 1,00 & 1,33 & 0,87 & 0,59 & \\
\hline Angry & 2,44 & 1,12 & 2,67 & 1,32 & $-0,22$ & \\
\hline Angry at self & 2,15 & 1,17 & 1,67 & 0,71 & 0,48 & \\
\hline Ashamed & 1,78 & 0,89 & 1,44 & 0,73 & 0,33 & \\
\hline Astonished & 2,19 & 1,00 & 1,78 & 0,97 & 0,41 & \\
\hline At ease & 2,44 & 1,19 & 3,00 & 1,32 & $-0,56$ & \\
\hline Attentive & 3,85 & 0,95 & 4,22 & 0,67 & $-0,37$ & \\
\hline Bashful & 1,93 & 1,14 & 1,11 & 0,33 & 0,81 & A \\
\hline Blameworthy & 1,96 & 1,09 & 1,56 & 0,53 & 0,41 & \\
\hline Blue & 1,48 & 0,80 & 1,22 & 0,44 & 0,26 & \\
\hline Bold & 3,30 & 1,23 & 4,11 & 1,05 & $-0,81$ & $\mathrm{~B}$ \\
\hline Calm & 3,56 & 1,09 & 4,33 & 0,71 & $-0,78$ & $\mathrm{~B}$ \\
\hline Cheerful & 3,41 & 0,97 & 3,89 & 0,78 & $-0,48$ & \\
\hline Concentrating & 4,15 & 0,66 & 4,33 & 0,50 & $-0,19$ & \\
\hline Confident & 3,44 & 1,19 & 4,33 & 0,50 & $-0,89$ & $\mathrm{~B}$ \\
\hline Daring & 2,74 & 1,02 & 3,22 & 1,20 & $-0,48$ & \\
\hline Delighted & 2,33 & 1,11 & 2,67 & 1,22 & $-0,33$ & \\
\hline Determined & 3,67 & 0,73 & 4,11 & 0,78 & $-0,44$ & \\
\hline Disgusted & 1,48 & 0,85 & 1,44 & 1,33 & 0,04 & \\
\hline Disgusted with self & 1,41 & 0,93 & 1,22 & 0,67 & 0,19 & \\
\hline Dissatisfied with self & 2,48 & 1,28 & 2,44 & 1,24 & 0,04 & \\
\hline Distressed & 2,15 & 0,99 & 1,44 & 0,73 & 0,70 & \\
\hline Downhearted & 2,37 & 1,11 & 1,67 & 1,00 & 0,70 & \\
\hline Drowsy & 1,59 & 0,75 & 1,22 & 0,44 & 0,37 & \\
\hline Energetic & 3,52 & 0,98 & 4,22 & 0,67 & $-0,70$ & \\
\hline Enthusiastic & 2,41 & 1,01 & 2,33 & 1,00 & 0,07 & \\
\hline Excited & 2,52 & 1,09 & 2,00 & 1,12 & 0,52 & \\
\hline Fearless & 2,48 & 1,34 & 2,89 & 1,45 & $-0,41$ & \\
\hline Fightened & 1,78 & 1,31 & 1,22 & 0,44 & 0,56 & \\
\hline Guilty & 2,26 & 1,13 & 1,22 & 0,44 & 1,04 & $\mathrm{~A}$ \\
\hline Happy & 3,07 & 1,11 & 3,89 & 0,78 & $-0,81$ & $\mathrm{~B}$ \\
\hline Hostile & 1,59 & 0,89 & 1,44 & 1,33 & 0,15 & \\
\hline Inspired & 2,56 & 1,09 & 3,33 & 1,22 & $-0,78$ & $\mathrm{~B}$ \\
\hline Interested & 3,93 & 0,73 & 4,22 & 0,67 & $-0,30$ & \\
\hline Irritable & 2,15 & 1,06 & 2,33 & 1,50 & $-0,19$ & \\
\hline Jittery & 1,70 & 0,91 & 1,11 & 0,33 & 0,59 & \\
\hline Joyful & 3,11 & 1,01 & 3,00 & 1,12 & 0,11 & \\
\hline Lively & 3,52 & 1,05 & 4,22 & 0,67 & $-0,70$ & \\
\hline Loathing & 1,78 & 1,15 & 1,11 & 0,33 & 0,67 & \\
\hline Lonely & 2,04 & 1,13 & 1,22 & 0,44 & 0,81 & A \\
\hline Nervous & 2,30 & 0,87 & 1,67 & 0,87 & 0,63 & \\
\hline Proud & 3,04 & 1,13 & 2,78 & 0,97 & 0,26 & \\
\hline Relaxed & 3,04 & 1,09 & 2,67 & 1,22 & 0,37 & \\
\hline $\mathrm{Sad}$ & 2,33 & 1,11 & 2,33 & 0,87 & 0,00 & \\
\hline Scared & 1,93 & 1,04 & 1,22 & 0,44 & 0,70 & \\
\hline Scornful & 1,37 & 0,74 & 1,33 & 0,71 & 0,04 & \\
\hline Shaky & 2,30 & 1,10 & 1,44 & 0,73 & 0,85 & $\mathrm{~A}$ \\
\hline Sheepish & 2,07 & 1,00 & 1,78 & 0,83 & 0,30 & \\
\hline Shy & 2,59 & 1,01 & 2,22 & 1,20 & 0,37 & \\
\hline Sleepy & 1,56 & 0,93 & 1,00 & 0,00 & 0,56 & \\
\hline Sluggish & 1,85 & 0,86 & 2,00 & 1,00 & $-0,15$ & \\
\hline Strong & 3,63 & 1,15 & 4,33 & 0,50 & $-0,70$ & \\
\hline Surprised & 2,52 & 1,01 & 2,00 & 0,87 & 0,52 & \\
\hline Timid & 2,11 & 1,05 & 1,22 & 0,44 & 0,89 & A \\
\hline Tired & 2,89 & 1,31 & 2,33 & 1,22 & 0,56 & \\
\hline Upset & 2,19 & 1,11 & 2,00 & 1,41 & 0,19 & \\
\hline
\end{tabular}


sad emotional expressions make him appear less efficient and followers who observe a sad leader feel less enthusiasm and more fatigue (Glaso et al. 2006).

There is usually a double standard for compulsory emotions inside organizations. Leaders must express emotions reflecting a state of inner psychic balance and rationality (Putnam and Mumby, 1993; Ashforth and Humphrey, 1993). Subordinates on the other hand are expected to behave towards their superiors with submission, respect and politeness, which might require suppression of strong positive or negative feelings (Rafaeli and Sutton, 1987; Fineman, 1993; Briner and Totterdell, 2002).

Anger, for example, is a prerequisite for leaders while being a luxury for subordinates (Tiedens, 2000). Although anger can lead to counterproductive work behaviours and often has a disruptive effect, anger is also a sign of power. Male leaders are perceived as more efficient when they show anger than when they show sadness or react with a neutral expression. Similarly, people attribute more power to a leader who shows anger than one who shows sadness.

Table 3 and Figure 2 indicate how much the emotions displayed by leaders differ from those displayed by subordinates. Letter 'A' spotlights emotions, which are displayed more often or more intense by leaders. Letter 'B' highlights emotions that are displayed by leaders less often or less intense than by subordinates.

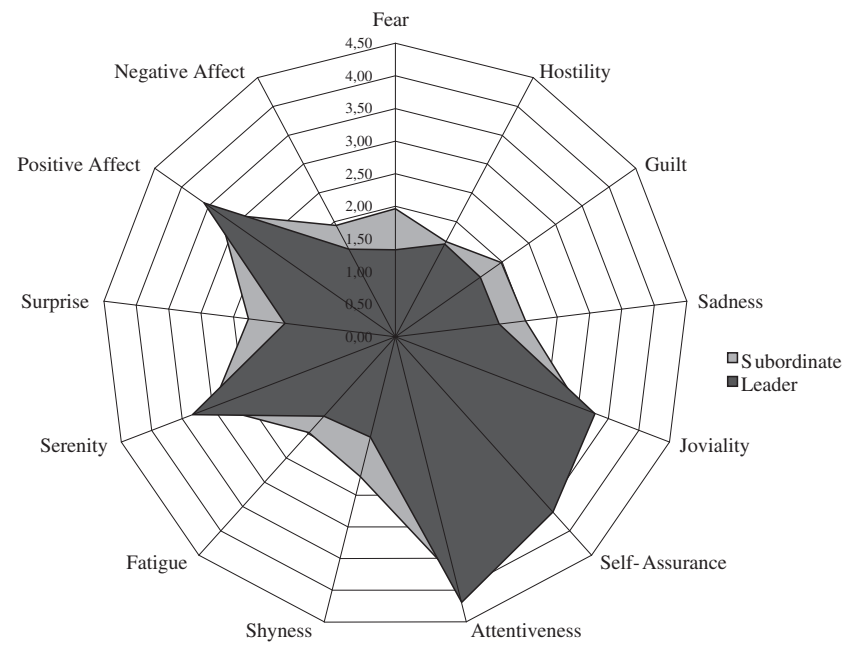

Figure 2: Difference in emotions displayed by leaders and subordinate

The difference between the leaders' and subordinates' displayed emotions is consistent with literature data cited above (Figure 2).

\section{Conclusions}

Emotions at the workplace are not ubiquitous but may be employed to foster organizational goals; this, however, needs to be done wisely because, as qualitative research shows, leaders do not always find their true feelings conform to their roles (Ashforth \& Toumiuk, 2000). As adequate feelings do not erupt spontaneously or automatically, leaders modify their display of emotions either by deep acting or by surface acting (Ashforth \& Humphrey, 1993; Hochschild, 1979, 2003). Emotions can be faked but this faking bears a price. A good emotional leader seeks ways to make employees' natural feelings be like those which are good for the job. Helping employees to be more empathic in their interactions with clients and creating an environment which is perceived as just, are two important means leading to this goal. But who gives a hand to leaders? Do they have to strive for proper emotions all by themselves for both their own and others' sake? Is emotional management a burden or a prospect for leaders?

The requirement to show organizationally demanded emotions was originally thought to be a source of stress leading to burnout. Firstly, a leader who uses his or her emotions strategically risks a necessity to "create" the right emotions for the right purpose on a regular basis. But those who on a daily basis feel obliged to 'fake' emotions and play an emotional role will experience emotional dissonance and hence be at risk for burnout in the long run.

The second problem is that the success of charismatic leadership is intrinsically based on the perception of the genuineness of a leader's emotions. Consequently, emotional behaviours that are simply used as tools may not work, but even have perverse side effects. Followers react negatively to a leader whose verbal message does not match their emotional expressions in emotional tone. Leaders who unsuccessfully try to mask their negative emotions are also likely to be perceived as manipulative and having selfserving intentions. This is why leaders should especially be adept in regulating their emotions perfectly all the time.

However, it turned out that frequency, duration and intensity of emotional labour are not systematically related to burnout. In fact, in a frequently cited article on emotional labour, Morris and Feldman (1997) argue that emotional labour need not to be uniformly or equally damaging to all individuals. They point out that not only are there cases where leaders simply go on automatic pilot, but that there are situations where emotional labour reduces uncertainty or helps avoid embarrassing interpersonal situations and hence may actually lead to increased job satisfaction. Due to personal or job characteristics, individuals in jobs with high levels of emotional labour may actually report higher levels of satisfaction and personal accomplishment, and suffer less from burnout. Showing leader-like emotions may result in increased self-esteem and improved leader-to-subordinate relationship, which further amplifies the leader's sense of worth.

\section{References}

Arvey, R. D., Renz, G. L., Watson, T. W. (1998): Emotionality and job performance: implications for personnel selection. Research in Personnel and Human Resources Management, 16. pp. 103-147.

Ashforth, B. E., Humphrey, R. H. (1993): Emotional labor in service roles: The influence of identity. Academy of Management Review, 18. pp. 88-115.

Ashforth, B. E., Humphrey, R. H. (1995): Emotion in the workplace: A reappraisal. Human Relations, 48. pp. 97-125. 
Ashforth, B. E., Tomiuk, M. A. (2000): Emotional labor and authenticity: Views from service agents. In S. Fineman (Ed), Emotions in organizations (pp. 184-203). New Delhi: SAGE

Bales, R. F. (1950): Interaction process analysis. New York: Addison-Wesley.

Briner, R. B. and Totterdell, P. (2002): 'The experience, expression and management of emotion at work', in P. Warr (Ed.) Psychology at Work, London: Penguin.

Cropanzano, R., James K., Konovsky, M. A. (1993): Dispositional affectivity as a predictor of work attitudes and job performance. Journal of Organizational Behavior, 14. pp. 595-606.

Damasio, A. (1994): Descartes' Error: Emotion, Reason and the Human Brain (New York: Avon Books).

Dasborough, M. T. and Ashkanasy, N. M. (2002): 'Emotion and attribution of intentionality in leader-member relationships', The Leadership Quarterly, Vol. 13, pp. 615-634.

Fineman, S. (Ed.) (1993): 'Organizations as emotional arenas', Emotion in Organizations, Thousand Oaks, CA: Sage, pp.9-35.

Fisher, C. D., Ashkanasy, N. M. (2000): Emotions in organizations. Journal of Organizational Behavior, 21. pp. 121-234.

Fleishman, E. A. (1957): A leader behavior description for industry. In R. M. Stogdill and A. E. Coons (eds.), Leader behavior: Its description and measurement. Columbus: Bureau of Business Research, Ohio State University.

George, J. M. (2000): 'Emotions and leadership: the role of emotional intelligence', Human Relations, Vol. 53, No. 8, pp.1027-1055.

Glaso, L., Ekerholt, K., Barman, S., Einarsen, S. (2006): The instrumentality of emotion in leader-subordinate relationships. International Journal of Work Organisation and Emotion, Vol. 1, No. 3, 2006

Goleman, D. (1995): Emotional Intelligence. New York: Bantam Books.

Hare, R. (1986): The social construction of emotions. New York: Basil Blackwell.

Hochschild, A. R. (1979): Emotion work, feeling rules, and social structure. American Journal of Administrative Science Quarterly, 36. pp. 245-268.

Hochschild, A. R. (1983): The managed heart: Commercialisation of human feeling. University of California Press, Berkeley.

Hodgkinson, C. (1990): Educational leadership: The Moral Art (Albany NY: State University of New York Press).

Humphrey, R. H. (2002): 'The many faces of emotional leadership', Leadership Quarterly, Vol. 13, pp.493-504.

Lazarus, R.S. (1991): Emotion and adaptation, New York: Oxford University Press.
Leithwood, K., Jantzi, D. and Steinbach, R. (1999): Changing Leadership for Changing Times (Philadelphia, Penn: Open University Press).

Likert, R. (1967): New patterns of management. New York: McGraw Hill

Mann, S. (1999): 'Emotion at work: to what extent are we expressing, suppressing, or faking it?', European Journal of Work and Organizational Psychology, Vol. 8, No. 3, pp.347-369.

Martin, S. E. (1999): Police force or police service? Gender and emotional labor. In: Steinberg R. J., Figart D. M. (Eds), Emotional labor in service economy. The Annals of the American Academy of Political and Social Science, 561. pp. 111-126.

Mills, T., Kleinman, S. (1988): Emotions, reflexivity, and action: An interactionist analysis. Social Forces, 66. pp. 1009-1027.

Morris, J. A., Feldman, D. C. (1997): Managing emotions in the workplace. Journal of Managerial Issues, 9. pp. 257-274.

Muchinsky, P. M. (2000): Emotions in the workplace: The neglect of organizational behavior. Journal of Organizational Behavior, 21. pp. 801-805.

Newcombe, M. J. and Ashkanasy, N. M. (2002): 'The role of affect and affective congruence in perceptions of leaders: an experimental study', Leadership Quarterly, Vol. 13, pp.601-614.

Putnam, L. L. and Mumby, D. K. (1993): 'Organizations, emotion, and the myth of rationality', in S. Fineman (Ed.) Emotion in Organizations, Thousand Oaks, CA: Sage, pp.36-57.

Rafaeli, A., Sutton, R. (1987): Expression of emotion as part of the work role. Academy of Management Review, 12. pp. 23-37.

Reilly, J., Seibert, L. (2003): 'Language and emotion', in R.J. Davidson, K.R. Scherer and H.H. Goldsmith (Eds.) Handbook of Affective Sciences, New York: Oxford University Press.

Strazdins, L. (2002): 'Emotional work and emotional contagion', in N.M. Ashkanasy, W.J. Zerbe and C.E.J. Härtel (Eds.) Managing Emotions in the Workplace, New York: M.E. Sharpe, pp.111-134.

Thoits, P. A. (1989): The sociology of emotions. Annual Review of Sociology, 15. pp. 317.

Tiedens, L. Z. (2000): 'Powerful emotions: the vicious cycle of social status positions and emotions', in N.M. Ashkanasy, C.E.J. Härtel and W.J. Zerbe (Eds.) Emotions in the Workplace. Research, Theory and Practice, Westport, CT: Quorum Books, pp.71-81.

Totterdell, P., Holman, D. (2003): Emotion regulation in customer service roles: Testing a model of emotional labor. Journal of Occupational Health Psychology, 8. pp. 55-73.

Watson, D., Clark, L. A. (1984): Negative affectivity: The disposition to experience negative emotional states. Psychological Bulletin, 96. pp. 465-490. 